\title{
Synthesis and characterization of sodium alkoxides
}

\author{
K CHANDRAN, R NITHYA ${ }^{\dagger}$, K SANKARAN, A GOPALAN ${ }^{\ddagger}$ and V GANESAN* \\ Materials Chemistry Division, ${ }^{\dagger}$ Materials Science Division, Indira Gandhi Centre for Atomic Research, \\ Kalpakkam 603 102, India \\ Department of Industrial Chemistry, Alagappa University, Karaikudi 630 006, India
}

MS received 21 April 2005; revised 4 February 2006

\begin{abstract}
Alcohol route is being adopted for cleaning sodium from sodium-wetted small components of coolant circuits of fast reactors. For better understanding of sodium-alcohol reactions and their energetics, the data on thermo-chemical properties such as heats of sodium-alcohol reactions, heats of dissolution, heat capacities, thermal decomposition behaviour, etc of their end products are essential. In order to generate such data, high purity sodium alkoxides, viz. sodium methoxide, sodium ethoxide and sodium $n$-propoxide, were prepared by reacting sodium metal with respective alcohol. These compounds were characterized using $\mathrm{X}$-ray diffraction technique and IR spectroscopy. The elemental analysis was carried out by CHNS analyser and atomic emission spectroscopy. Normal chain sodium alkoxides were found to exhibit tetragonal crystal structure. Crystal structures of sodium ethoxide and sodium $n$-propoxide are reported for the first time. The IR spectrum of sodium $n$-propoxide is also reported for the first time.
\end{abstract}

Keywords. Sodium methoxide; sodium ethoxide; sodium $n$-propoxide; IR spectra; X-ray diffraction; crystal structure.

\section{Introduction}

Favourable physical, chemical and nuclear properties as well as cost make sodium an attractive choice as coolant among other metals and alloys for LMFBRs (Walter and Reynolds 1981). Structural materials and components such as valves, pumps, impurity monitoring devices, subassemblies, etc which are in physical contact with liquid sodium, get wetted with thin layer of sodium on the surface due to long exposure and high temperatures (Jordan and Lane 1967; Longson and Thorley 1967; Borgstedt and Mathews 1987). These components, when taken out for maintenance or disposal, need to be cleaned free of sodium for the following purposes: (i) to protect maintenance personnel from the chemical hazards of sodium or from exposure to radiation in the case of primary components, (ii) to carry out inspection, maintenance and repair work and (iii) to avoid corrosion or mechanical damage by the product of sodium cleaning, viz. sodium hydroxide, on components that are to be re-used.

Bulk sodium from components can be removed by melting and draining. Traces of sodium sticking onto the surface of components due to wetting can be removed by (i) in situ vacuum distillation method, which is a highly energy intensive process (Lutton et al 1980) and (ii) chemical method in which the highly reactive elemental sodium is converted into non-reactive/less reactive sodium compound by suitable processes (Lutton et al 1980).

\footnotetext{
*Author for correspondence (ganesh@igcar.gov.in)
}

Low molecular weight alcohols viz. methanol and ethanol, are generally employed for cleaning sodium-wetted small components such as valves, bellows, etc. The international scenario on sodium removal using different alcohols are summarized and given in table 1. For better understanding of sodium-alcohol reaction and sodium alkoxide products, data such as heats of reaction, heats of dilution, heats of formation, heat capacities, thermal decomposition and solubilities of alkoxides in their respective alcohol are essential. There are limited or no data available in the literature on many of these properties. In order to generate data on these properties, high purity sodium alkoxides, viz. methoxide, ethoxide and $n$-propoxide, of sodium were prepared and characterized. The crystal structure of sodium ethoxide and sodium $n$-propoxide are reported for the first time. IR spectra of sodium methoxide, sodium ethoxide and sodium $n$-propoxide by $\mathrm{KBr}$ pellet method are reported. The reports available on synthesis of different alkoxides of alkali metals are summarized in table 2. The present work gives complete account of preparation, crystal structure and compositional characterization of some of the sodium alkoxides, viz. sodium methoxide, sodium ethoxide and sodium $n$-propoxide.

\section{Experimental}

\subsection{Chemicals}

The nuclear grade sodium (purity: 99.5\%) from M/s Alkali Metals Pvt. Ltd., India, was further purified by vacuum 
Table 1. The summary of international scenario on sodium removal processes using various alcohols.

\begin{tabular}{|c|c|c|}
\hline Country & Facility & Solvent used \\
\hline $\begin{array}{l}\text { China } \\
\text { (Waimei et al 1997) }\end{array}$ & China Institute of Atomic Energy & $\begin{array}{l}\text { 1. Ethanol } \\
\text { 2. Butyl cellosolve }\end{array}$ \\
\hline $\begin{array}{l}\text { France } \\
\text { (Marmonier and Negro 1997) }\end{array}$ & RAPSODIE & Ethyl carbitol \\
\hline $\begin{array}{l}\text { Germany } \\
\text { (Stade 1978) }\end{array}$ & KNK & Methanol + dry ice \\
\hline $\begin{array}{l}\text { Germany } \\
\text { (Haubold 1978) }\end{array}$ & Interatom $\mathrm{GmbH}$ & Ethanol \\
\hline $\begin{array}{l}\text { Germany } \\
\text { (Minges et al 1997) }\end{array}$ & Institute für Reaktorsicherheit & Ethyl carbitol \\
\hline $\begin{array}{l}\text { India } \\
\text { (Jambunathan et al 1997; Rajan et al 1997) }\end{array}$ & IGCAR & Ethanol \\
\hline $\begin{array}{l}\text { Italy } \\
\text { (Caponetti et al 1984; Caponetti 1985) }\end{array}$ & Centro Ricerche Energia Casaccia & Butyl cellosolve \\
\hline $\begin{array}{l}\text { Italy } \\
\text { (DeLuca et al 1978) }\end{array}$ & CSN, Casaccia & Butyl cellosolve $+\mathrm{NN}$ dimethylformamide \\
\hline $\begin{array}{l}\text { Japan } \\
\text { (Mukaibo et al 1978) }\end{array}$ & JOYO & Ethanol $+10 \% \mathrm{H}_{2} \mathrm{O}$ \\
\hline $\begin{array}{l}\text { Japan } \\
\text { (Nakai et al 1997) }\end{array}$ & OEC, MONJU & Ethanol $+10 \% \mathrm{H}_{2} \mathrm{O}$ \\
\hline $\begin{array}{l}\text { UK } \\
\text { (Donaldson and Bray 1978) }\end{array}$ & Dounreay Nuclear Power Establishment & Butyl cellosolve \\
\hline $\begin{array}{l}\text { USA } \\
\text { (Steele and Brehm 1978) }\end{array}$ & $\begin{array}{l}\text { 1. SRDA } \\
\text { 2. Sodium removal facility } \\
\text { 3. Na/APF }\end{array}$ & $\begin{array}{l}\text { Denatured ethanol } \\
\text { Dowanol PM } \\
\text { Ethanol }\end{array}$ \\
\hline $\begin{array}{l}\text { USA } \\
\text { (Welch and Steele 1978) }\end{array}$ & Atomics International Division & $\begin{array}{l}\text { Denatured ethanol } \\
\text { Denatured ethanol + acetic acid }\end{array}$ \\
\hline $\begin{array}{l}\text { USA } \\
\text { (Asquith et al 1976) }\end{array}$ & Atomics International Division & Jaysol SS \\
\hline
\end{tabular}

Table 2. Summary of synthesis of various sodium alkoxides.

\begin{tabular}{|c|c|}
\hline Author & Method of preparation \\
\hline Grenter and Westrum (1957) & $\mathrm{Na}+\mathrm{CH}_{3} \mathrm{OH} \rightarrow \mathrm{CH}_{3} \mathrm{ONa}+1 / 2 \mathrm{H}_{2} \uparrow$ \\
\hline Weiss (1964) & $\mathrm{Na}+\mathrm{CH}_{3} \mathrm{OH} \mathrm{CH}{ }_{3} \mathrm{ONa}+1 / 2 \mathrm{H}_{2} \uparrow$ \\
\hline Blanchard et al (1976) & $\mathrm{M}+\mathrm{C}_{2} \mathrm{H}_{5} \mathrm{OH} \rightarrow \mathrm{C}_{2} \mathrm{H}_{5} \mathrm{OM}+1 / 2 \mathrm{H}_{2} \uparrow[\mathrm{M}=\mathrm{Li}, \mathrm{Na}, \mathrm{K}]$ \\
\hline Vacek et al (1984) & $\begin{aligned} \mathrm{C}_{n} \mathrm{H}_{2 n+1} \mathrm{ONa}+\mathrm{ROH} \rightarrow & \mathrm{RONa}+\mathrm{C}_{n} \mathrm{H}_{2 n+1} \mathrm{OH} \\
& {\left[n=3 \text { to } 5 ; \mathrm{R}=-\mathrm{CH}_{3},-\mathrm{C}_{2} \mathrm{H}_{5}\right] } \\
\mathrm{NaOH}+\mathrm{ROH} \rightarrow \mathrm{RONa}+\mathrm{H}_{2} \mathrm{O} & \\
& {\left[\mathrm{R}=-\mathrm{C}_{3} \mathrm{H}_{7},-\mathrm{C}_{4} \mathrm{H}_{9},-\mathrm{C}_{5} \mathrm{H}_{11}\right] }\end{aligned}$ \\
\hline Sridhar (1996) & $\underset{\text { [electrolysis] }}{\mathrm{CH}_{3} \mathrm{COONa}+\mathrm{CH}_{3} \mathrm{OH} \rightarrow \mathrm{CH}_{3} \mathrm{ONa}+\mathrm{CH}_{3} \mathrm{COOH}}$ \\
\hline Ely et al (2002) & $\begin{array}{l}\mathrm{M}+\mathrm{ROH} \rightarrow \mathrm{ROM}+\mathrm{H}_{2} \uparrow \\
{[\mathrm{M}=\text { mixture of alkali }+ \text { alkaline earth metals }]}\end{array}$ \\
\hline Evdokimov et al (2002) & $\begin{array}{l}\mathrm{M}_{2} \mathrm{CO}_{3}+2 \mathrm{ROH} \rightarrow 2 \mathrm{ROM}+\mathrm{CO}_{2} \uparrow+1 / 2 \mathrm{H}_{2} \mathrm{O} \\
{\left[\mathrm{M}=\mathrm{Li}, \mathrm{Na}, \mathrm{K} ; \mathrm{R}=-\mathrm{CH}_{3},-\mathrm{C}_{2} \mathrm{H}_{5}\right]}\end{array}$ \\
\hline Present work & $\begin{array}{r}\mathrm{Na}+\mathrm{ROH} \rightarrow \mathrm{RONa}+1 / 2 \mathrm{H}_{2} \uparrow \\
{\left[\mathrm{R}=-\mathrm{CH}_{3},-\mathrm{C}_{2} \mathrm{H}_{5},-n \mathrm{C}_{3} \mathrm{H}_{7}\right]}\end{array}$ \\
\hline
\end{tabular}


distillation method (Ganesan et al 1986). HPLC grade methanol (purity: 99.8\%) from M/s Ranbaxy Fine Chem. Ltd., India, absolute ethanol (purity: $99.9 \mathrm{v} / \mathrm{v} \%$ ) from $\mathrm{M} / \mathrm{s}$ Hayman, UK and AR grade $n$-propanol (purity: $>99.5 \%$ ) from M/s S.D. Fine Chem. Ltd., India, were used for the synthesis of sodium alkoxides. These solvents were further purified by distillation method (Furniss et al 1980). Moisture content of the alcohols were measured by Karl Fischer coulometric titration and found to be in the range $0 \cdot 04-0 \cdot 08 \%$.

\subsection{Experimental set up}

Sodium readily forms sodium oxide and sodium hydroxide when exposed to oxygen and moisture, respectively. Sodium-alcohol reaction product viz. the sodium alkoxide, is highly moisture sensitive forming sodium hydroxide and the corresponding alcohol when exposed even in trace level. Therefore, synthesis and preservation of sodium alkoxides need a high degree of inert atmosphere. A high purity argon atmosphere glove box (meant for handling liquid alkali metals) was used to handle and preserve these compounds (Borgstedt and Mathews 1987). The experimental set up used for the preparation of high purity sodium alkoxide was made of borosilicate glass with standard ground glass with provisions for sodium addition and purging argon cover gas.

\subsection{Preparation of sodium alkoxides}

The formation of sodium alkoxides and subsequent separation of pure sodium alkoxide crystals can be represented by the following reactions:

$$
\begin{aligned}
& \mathrm{Na}+\mathrm{ROH}_{\text {excess }} \rightarrow[\mathrm{RONa}]_{\mathrm{ROH}}+1 / 2 \mathrm{H}_{2} \\
& (\mathrm{R}=\text { methyl, ethyl and } n \text {-propyl }) \\
& {[\mathrm{RONa}]_{\mathrm{ROH}} \stackrel{\text { Vacuum distillation }}{\longrightarrow} \mathrm{RONa}+\mathrm{ROH} .}
\end{aligned}
$$

About $100 \mathrm{ml}$ of alcohol was taken in the reaction vessel and stirred continuously using a magnetic stirrer. Argon gas, purified by passing through a column of silica-gel to remove traces of moisture, was let into the reaction vessel to provide inert gas cover while carrying out sodiumalcohol reaction as well as to dilute the hydrogen gas produced during the reaction. Solid sodium pieces weighing 500-1000 mg were added to the alcohol. The reaction was initially carried out at room temperature and then the temperature was gradually raised to near boiling point of the respective alcohol to dissolve as much sodium as possible and the addition of sodium was stopped when the solution was saturated. Stirring and heating were stopped and the saturated sodium alkoxide solution was allowed to cool naturally for about $16 \mathrm{~h}$ to facilitate formation of sodium alkoxide crystals and completion of crystalliza- tion process. The excess alcohol was then removed by vacuum distillation and the evolved alcohol was trapped by condensing the vapour in a thermostat trap maintained at $183 \mathrm{~K}$ using liquid nitrogen-acetone slurry. The crystalline sodium alkoxide was dried under a dynamic vacuum of $10^{-2}$ mbar for $16 \mathrm{~h}$ at room temperature and then at high vacuum of $10^{-5}$ mbar for $8 \mathrm{~h}$. The drying process was carried out initially at $303 \mathrm{~K}$ for $8 \mathrm{~h}$ and the remaining period at $323 \mathrm{~K}$. Dry milky white fine crystals of sodium alkoxides were transferred into a leak tight glass container and preserved in a high purity argon atmosphere glove box. A typical photograph showing crystalline sodium $n$-propoxide is shown in figure 1.

\subsection{Characterization}

\subsubsection{Elemental analysis}

2.4.1a Analysis of carbon and hydrogen: Approximately $7-11 \mathrm{mg}$ of dry sodium alkoxide powder was loaded in special tin crucibles of size $3.5 \times 9.0 \times 0.1 \mathrm{~mm}$ (Elementar Vario EL, Germany) inside the argon atmosphere glove box and hermetically sealed by crimping at the top of the crucible. After crimping, weights of the samples were measured as a function of time over a period of $10 \mathrm{~h}$ in air. The weight of each sample was found to be unchanged thus confirming leak tightness of the crucibles. These crucibles were loaded in the CHNS elemental analyser (Elementar Vario EL, Germany) for measurement of carbon and hydrogen contents. Combustion and thermal conductivity measurements were involved in the analysis. High purity sulfanilic acid, benzoic acid and mandelic acid (M/s MERK, > 99\%) were used as standards and the analyses showed that the error involved was $<1 \%$. Sodium benzoate (A.R. grade purity : 99.0\% from Samir Tech-Chem Industry, India), a sodium substituted compound was also analysed to cross check the carbon and hydrogen contents with that of the sodium alkoxides.

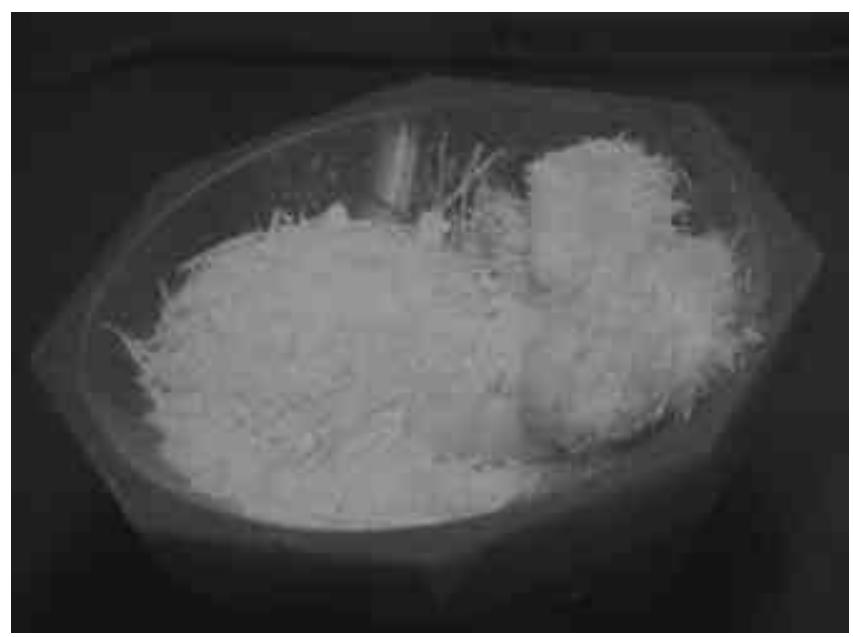

Figure 1. Typical crystals of sodium $n$-propoxide. 
2.4.1b Analysis of sodium: Stock solutions were made by dissolving about $50-60 \mathrm{mg}$ of dry sodium alkoxide powder in distilled water. Necessary dilutions were made by taking aliquot from these stock solutions and used for analysis. Calibration was carried out using sodium chloride standard solution in the concentration range 1-7 $\mu \mathrm{g} \mathrm{ml}^{-1}$. The samples were analysed for sodium content using atomic absorption/emission spectrometer (Instrumental Laboratory Inc., Model 751, USA) in emission mode.

\subsubsection{Infrared analysis}

IR spectra of sodium alkoxides were recorded in Nujal mull and in pressed $\mathrm{KBr}$ pellets. The $\mathrm{KBr}$ pellet was sandwiched between two ZnSe windows with a Teflon washer placed in between the windows. The $\mathrm{ZnSe}$ windows were fitted in a sample holder, where leak tight arrangements were made using silicone ' $O$ ' ring, nylon retainer ring with a metal cap thus protecting the sample from exposure to moisture. All these operations were carried out inside an argon atmosphere glove box to prevent exposure of the alkoxides to moisture. The sample assembly, kept in a zipper poly bag filled with argon gas, was taken out from the glove box and preserved in argon atmosphere till it was placed in the IR specimen chamber. The IR spectrum of the sample was recorded using BOMEM MB100 Fourier Transform Infrared Spectrometer, (USA) in the range $4000-400 \mathrm{~cm}^{-1}$ with $4 \mathrm{~cm}^{-1}$ resolution.

\subsubsection{X-ray diffraction analysis}

The purity of sodium alkoxides were checked by a powder X-ray diffractometer (STOE, Germany) at room temperature with $\mathrm{CuK}_{\alpha}$ radiation $(\lambda, 1.5406 \AA)$. Dry sodium alkoxide powder was ground thoroughly and loaded in Lindemann glass capillary of $1 \mathrm{~mm}$ diameter, $30 \mathrm{~mm}$ height and sealed using paraffin wax in argon atmosphere glove box. The X-ray powder diffraction patterns were recorded in the angular range of $5-65^{\circ}$ with a step size of $0 \cdot 05^{\circ}$. The scan rate was $20 \mathrm{~s}$ per step.

\section{Results and discussion}

The results of carbon and hydrogen analysis of sodium alkoxides are given in table 3 along with the data obtained for sodium benzoate and other standards. It can be seen from table 3 that the values obtained for the standards were in excellent agreement with that calculated theoretically. It was observed that the values of carbon and hydrogen for sodium alkoxides deviated slightly from the theoretical values. This is expected because of high sensitivity of these compounds to moisture. During the analysis, these compounds were heated to very high temperature $(1423 \mathrm{~K})$ for combustion, which could result in possible loss of leak tightness of the sample holder and ingress of moisture into the samples. The data obtained from sodium analysis is given in table 4 . The values that are obtained in the present study are in excellent agreement with the theoretical values.

Figures $2 \mathrm{a}-\mathrm{c}$ show IR spectra of the methoxide, ethoxide and $n$-propoxide of sodium, respectively in $\mathrm{KBr}$ pellet. The IR spectra showed features around 3000, 1450 and $1050 \mathrm{~cm}^{-1}$. The 3000 and $1450 \mathrm{~cm}^{-1}$ features are due to $\mathrm{C}-\mathrm{H}$ stretching and bending vibrations of alkoxides. The feature around $1050 \mathrm{~cm}^{-1}$ is due to $\mathrm{C}-\mathrm{O}$ vibration. No features were seen around 3500 and $1600 \mathrm{~cm}^{-1}$ regions indicating the absence of $-\mathrm{OH}$ group in the compound, which show that the product is completely free from alcohol and solvated alkoxides. However, with the passage of time the sample was found to absorb moisture as evidenced by the increase in the intensity of the $3500 \mathrm{~cm}^{-1}$ peak.

The $\mathrm{C}-\mathrm{O}$ feature for sodium methoxide appears as doublet at 1070 and $1088 \mathrm{~cm}^{-1}$, which shows a marked difference from the $\mathrm{C}-\mathrm{O}$ feature of methanol occurring at $1032 \mathrm{~cm}^{-1}$. Similar shifts were observed in the $\mathrm{C}-\mathrm{O}$ features of sodium ethoxide and sodium $n$-propoxide from their $\mathrm{C}-\mathrm{O}$ features of the respective alcohols. The hydrogen atom of $-\mathrm{OH}$ group in the alcohol is replaced with sodium metal in the alkoxide making the electrons flow towards the $\mathrm{O}-\mathrm{Na}$ bond thereby making the $\mathrm{C}-\mathrm{O}$ bond strong and hence a blue shift of the $\mathrm{C}-\mathrm{O}$ feature is seen in the alkoxide.

Table 3. Elemental analysis by CHNS analyser.

\begin{tabular}{lcc}
\hline Compound & Carbon $(w t \%)^{*}$ & Hydrogen $(w t \%)^{*}$ \\
\hline Sulfanilic acid & $41.53 \pm 0.09(41.57)$ & $3.82 \pm 0.12(4.04)$ \\
Benzoic acid & $68.45 \pm 0.30(68.88)$ & $5.05 \pm 0.21(4.92)$ \\
Mandelic acid & $63.35 \pm 0.05(63.19)$ & $5.58 \pm 0.01(5 \cdot 26)$ \\
Sodium benzoate & $56.82 \pm 0.08(57.71)$ & $3.43 \pm 0.08(3.43)$ \\
Sodium methoxide & $21.33 \pm 0.31(22.23)$ & $5.82 \pm 0.35(5.60)$ \\
Sodium ethoxide & $33.58 \pm 0.62(35.29)$ & $7.53 \pm 0.29(7.41)$ \\
Sodium $n$-propoxide & $40.94 \pm 0.37(43.29)$ & $7.83 \pm 0.02(8.60)$ \\
\hline
\end{tabular}

*Theoretical composition given in parenthesis and oxygen not analysed. 
The IR spectra of sodium methoxide and ethoxide recorded in the present study using mull and $\mathrm{KBr}$ methods match exactly with that reported in literature (Pouchert 1981). However, the IR spectrum of sodium $n$-propoxide obtained in this work using mull as well as $\mathrm{KBr}$ methods is reported for the first time.

Powder X-ray diffraction pattern of sodium methoxide is shown in figure $3 \mathrm{a}$. All the peaks match well with those reported (JCPDS 19-1876) for anhydrous sodium methoxide except the small ones at $2 \theta=10 \cdot 1$ and $37 \cdot 0$. The peaks corresponding to $10 \cdot 1$ and 37.0 are due to sodium hydroxide formed on absorption of moisture by sodium methoxide (JCPDS 19-1877). Setting aside these two peaks, the remaining peaks corresponding to anhydrous sodium methoxide could be indexed to a tetragonal sys-
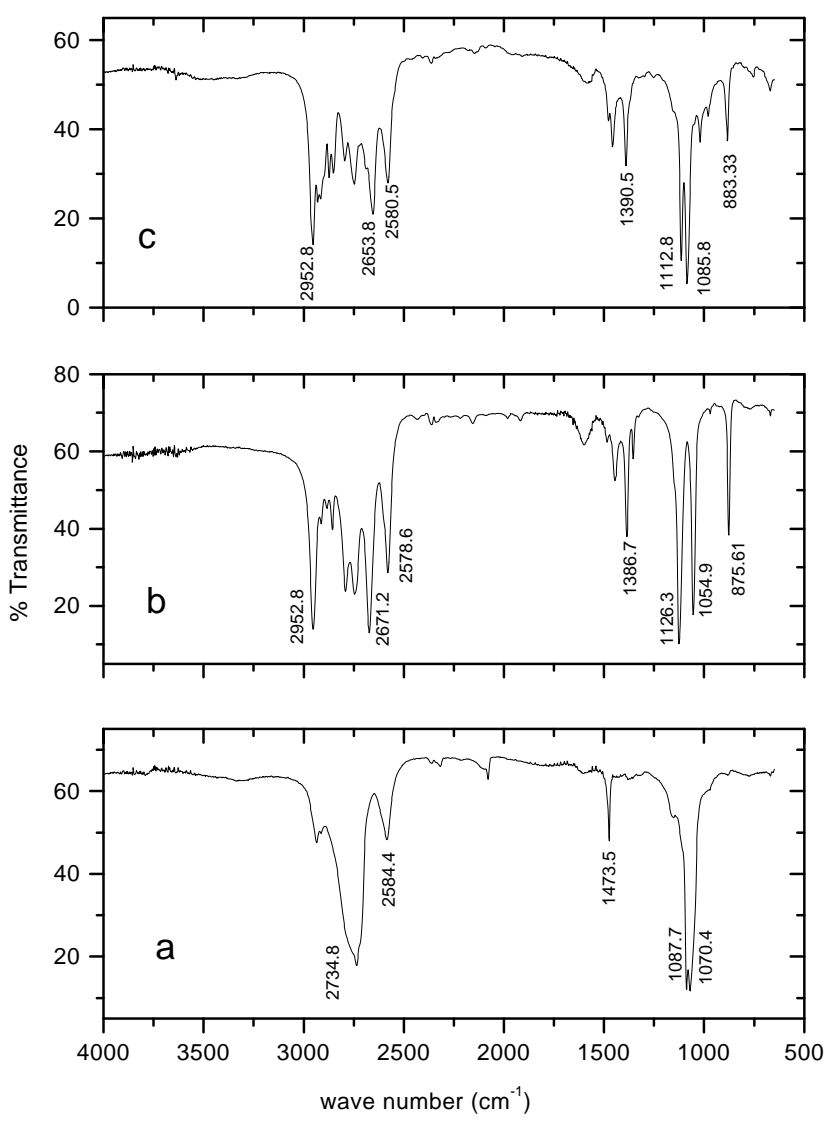

Figure 2. IR spectra of sodium a. methoxide, b. ethoxide and c. $n$-propoxide.

Table 4. Sodium analysis results by atomic emission spectroscopy.

\begin{tabular}{lc}
\hline Compound & Sodium content (wt.\%)* \\
\hline Sodium methoxide & $42.72 \pm 2 \cdot 09(42 \cdot 57)$ \\
Sodium ethoxide & $33.80 \pm 0.63(33.79)$ \\
Sodium $n$-propoxide & $28.18 \pm 0.09(28.01)$ \\
\hline
\end{tabular}

*Theoretical composition given in parenthesis. tem with $P 4 / n m m$ (129) space group. Initially the diffraction peaks in the range of $5-65^{\circ}$ were identified and fitted using a pattern fitting module available with WinXPow software of STOE diffractometer. The peaks thus fitted were indexed and starting lattice parameters were found, which were further refined from a least square refinement by index and refine module of WinXPow. The refined parameters ' $a$ ' and ' $c$ ' are 4.3404(12) and 7.412(4) $\AA$, respectively which are in agreement with the cell constants reported by Weiss (1964). Even though extreme care was taken while preparing and storing these compounds in inert atmosphere, owing to high affinity towards moisture as stated earlier, these compounds get hydrolysed although to an extremely small extent. The reactivity of sodium alkoxides towards moisture decreases with increase in carbon chain. This could be seen from the X-ray diffraction pattern of sodium methoxide that the relative peak intensity due to sodium hydroxide viz. peaks at $2 \theta=10 \cdot 1$ and $37 \cdot 0$, in the case of sodium methoxide is nearly $5 \%$, while it is less than $1 \%$ in the case of sodium ethoxide (9.0 and 35.0) and the same was not present in sodium $n$-propoxide.
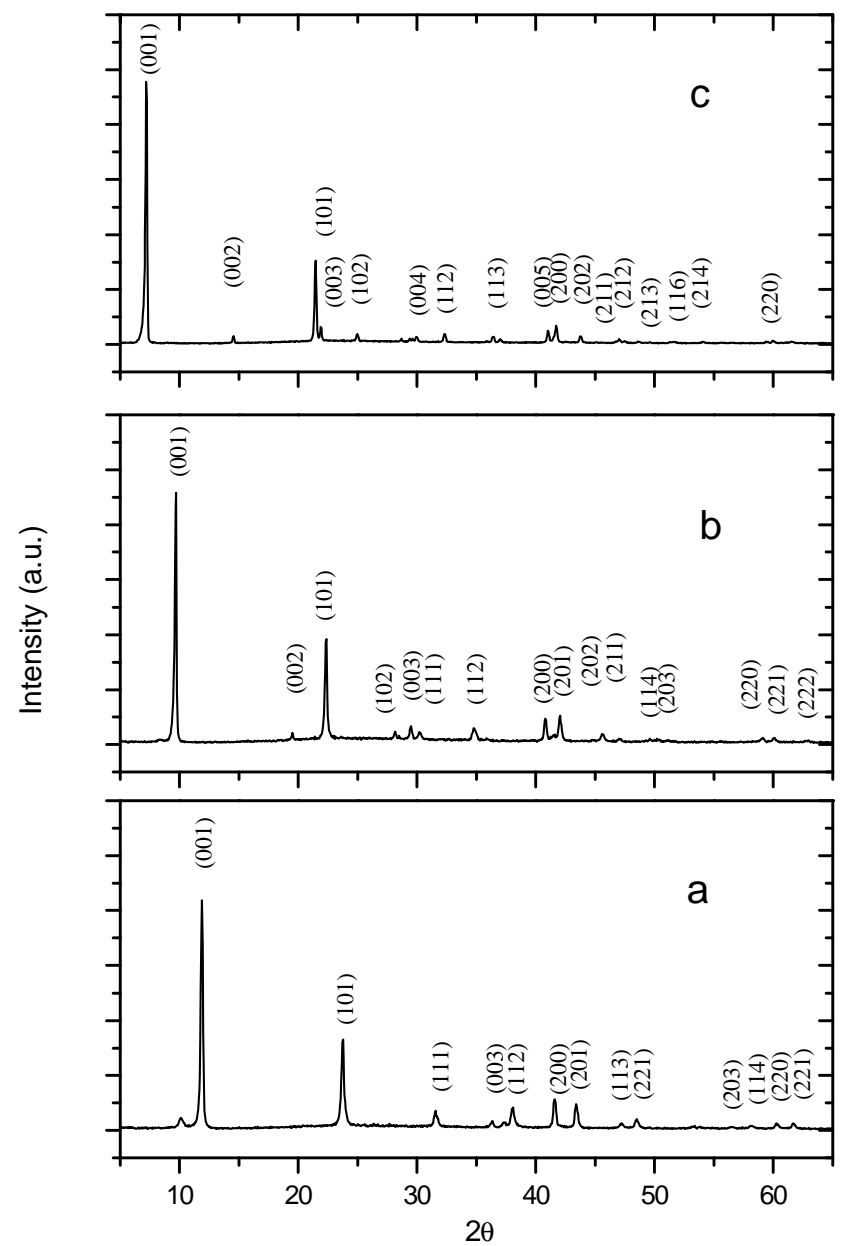

Figure 3. X-ray diffraction pattern of sodium a. methoxide, b. ethoxide and c. $n$-propoxide. 


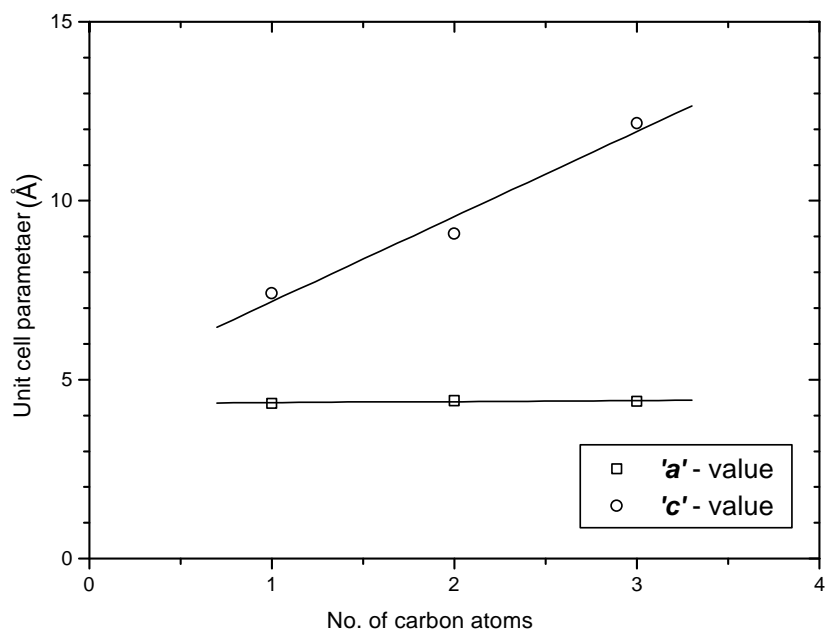

Figure 4. Comparison of unit cell parameters of the sodium alkoxides as a function of number of carbon atoms in the chain.

Similar procedure was followed to estimate the crystal system and cell constants for sodium ethoxide and sodium $n$-propoxide. Although the X-ray diffraction pattern is available for sodium ethoxide (JCPDS 31-1885), information on its crystal structure does not exist. XRD pattern obtained in the present study is shown in figure 3b. Sodium ethoxide also exhibits tetragonal structure with space group $P 4 / \mathrm{nmm}$ (129). The cell constants, $a$ and $c$, are 4.4215(6) and 9.088(24) $\AA$, respectively.

For sodium $n$-propoxide, X-ray diffraction crystallographic data are not available in the literature. The X-ray diffraction pattern of this compound obtained in the present study is shown in figure $3 \mathrm{c}$. All the peaks could be indexed to a tetragonal system with a P4/nmm (129) space group. The refined lattice constants ' $a$ ' and ' $c$ ' are 4.3994(9) and 12·166(21) A, respectively.

Normal chain sodium alkoxides taken in the present work exhibit tetragonal crystal structure. The variation of lattice parameters ' $a$ ' and ' $c$ ' were plotted against number of carbon atoms in the chain as shown in figure 4 . It is clear from the figure that the unit cell elongates in the ' $c$ ' direction as the number of carbon atoms increase while the lattice parameter ' $a$ ' remains constant.

\section{Conclusions}

The compounds, sodium methoxide, sodium ethoxide and sodium $n$-propoxide, were prepared in pure state in spite of their high reactivity to moisture. The elemental analysis of carbon and hydrogen in these compounds were carried out using CHNS analyser. The results of estimation of sodium in these compounds by AES technique match very well with the theoretical values indicating high purity of these compounds.
The IR spectra for sodium methoxide, sodium ethoxide and $n$-propoxide were recorded with mull and $\mathrm{KBr}$ in the present study. The IR spectrum of sodium $n$-propoxide is reported for the first time.

Analysis of sodium methoxide using X-ray powder diffraction method revealed tetragonal crystal structure and the measured lattice parameters matched very well with that reported in literature. The X-ray powder diffraction pattern for sodium ethoxide agrees well with the literature data although the lattice parameters and crystal structure were not reported. In the present work the crystal structure of sodium ethoxide was identified as tetragonal and the lattice parameters were measured and reported for the first time. In the case of sodium $n$-propoxide the $\mathrm{X}$ ray diffraction data is not available in the literature and the same is measured and reported for the first time. Sodium alkoxides taken in the present study exhibit tetragonal system with a constant ' $a$ ' parameter while the unit cell is found to elongate along the ' $c$ ' direction with increase in carbon chain length.

\section{Acknowledgements}

The authors are grateful to Dr G Periaswami, Materials Chemistry Division, IGCAR, for his constant encouragement throughout the course of the study and useful suggestions during the preparation of this paper. The authors thank Dr K S Viswanathan for his help in recording IR spectra and discussions during the course of this work and Dr K V G Kutty for X-ray powder diffraction analysis. Thanks are also due to Mr C V S Bramananda Rao for carrying out carbon and hydrogen analysis and to $\mathrm{Mr}$ A Thiruvengadasami for help in analysis of sodium alkoxides using AES.

\section{References}

Asquith J G, Steele O P and Welch F H 1976 Sodium removal technology - The alcohol process, in Proceedings of international conference on liquid metal technology in energy production (Pennsylvania: Champion) p. 548

Blanchard J M, Bousquet J, Claudy P and Letoffe J M 1976 J. Therm. Anal. 9191

Borgstedt H U and Mathews C K 1987 Applied chemistry of the alkali metals (NY, London: Plenum Press)

Caponetti R, Diamanti M and Iacovelli M 1984 Sodium removal and technology at Casaccia CRE, Liquid metal engineering and technology (London: BNES) p. 141

Caponetti R 1985 J. Nucl. Tech. 70408

DeLuca B, Grasso C and Spadonai M 1978 Cleaning of small components of complex geometry by means of the sodiumalcohol reaction, IAEA/IWGFR-Specialists meeting on sodium removal and decontamination, IWGFR-23, Richland, Washington, USA (Vienna: IAEA) p. 139

Donaldson D M and Bray J A 1978 UK fast reactor components-Sodium removal decontamination and requalification, 
IAEA/IWGFR_Specialists meeting on sodium removal and decontamination, IWGFR-23 Richland, Washington, USA (Vienna: IAEA) p. 110

Ely, Wayne B, Renner and Andrew C 2002 Production of alcoholates, Patent No. US 6372947

Evdokimov A N, Kurzin A V, Maiorova E D, Platonov A Y, Sivakov A A and Chistokletov V N 2002 Method for preparing alkali metal alcoholates from precalcined alkali metal carbonates and alcohols, Patent No. RU 2178402

Furniss B S, Hannaford A J, Rogers V, Smith P W G and Tatchell A R (eds) 1980 Vogel's text book of practical organic chemistry including qualitative organic analysis (London: The English Language Book Society and Longman Group Ltd) 4th ed.

Ganesan V, Krishnamoorthy D and Bhat N P 1986 Determination of oxygen in sodium by the vacuum distillation method, Report IGC-87

Grenter G and Westrum F J R 1957 J. Am. Chem. Soc. 791802

Haubold W 1978 INTERATOM Experience of cleaning sodium-wetted components, IAEA/IWGFR - specialists meeting on sodium removal and decontamination, IWGFR-23, Richland, Washington, USA (Vienna: IAEA) p. 42

Jambunathan D, Rao M S, Krishnamachari V S, Kasiviswanathan K V and Rajan M 1997 Experience on sodium removal from FBTR components in its operating phase, IAEA/ IWGFR-Technical committee meeting on sodium removal and disposal from LMFRs in normal operation and in the framework of decommissioning, IWGFR-98, Aix-en-Provence, France (Vienna: IAEA)

JCPDS - International Centre for Diffraction Data. PDF-2 database 1999 File 19-1876

JCPDS - International Centre for Diffraction Data. PDF-2 database 1999 File 19-1877

JCPDS - International Centre for Diffraction Data. PDF-2 database 1999 File 31-1885

Jordan D O and Lane J E 1967 The alkali metals, An international symposium held at Nottingham, 19-22 July 1966, Special publication No. 22 (London: The Chemical Society) p. 147

Longson B and Thorley A W 1967 The alkali metals, international symposium held at Nottingham, 19-22 July 1966, Special Publication No. 22 (London: The Chemical Society) p. 153

Lutton J M, Colburn R P and Welch F 1980 Atomic Energy Rev. 18815

Marmonier P and Del Negro C J 1997 Information about the accident occurred near RAPSODIE, IAEA/IWGFR - technical committee meeting on sodium removal and disposal from LMFRs in normal operation and in the framework of decommissioning, IWGFR-98, Aix-en-Provence, France (Vienna: IAEA)
Minges J, Cherdron W and Schutz W 1997 Short report of an accident during sodium cleanup with ethyl carbitol in a storage tank of a research facility, IAEA/IWGFR-technical committee meeting on sodium removal and disposal from LMFRs in normal operation and in the framework of decommissioning, IWGFR-98, Aix-en-Provence, France (Vienna: IAEA)

Mukaibo R, Matsuno Y, Sato I, Yoneda Y and Sato H 1978 Sodium removal from the grapples of the fuel handling facility of JOYO, IAEA/IWGFR - Specialists meeting on sodium removal and decontamination, IWGFR-23, Richland, Washington, USA (Vienna: IAEA) p. 63

Nakai S, Yamamoto S, Akai and Yatabe T 1997 Sodium removal by alcohol process, IAEA/IWGFR - technical committee meeting on sodium removal and disposal from LMFRs in normal operation and in the framework of decommissioning, IWGFR-98, Aix-en-Provence, France (Vienna: IAEA)

Pouchert C J 1981 The Aldrich library of infrared spectra (Milwaukee; Aldrich Chemical Co.) 3rd ed.

Rajan K K, Gurumoorthy K, Rajan M and Kale R D 1997 Sodium cleaning and disposal methods in experimental facilities, IAEA/IWGFR - technical committee meeting on sodium removal and disposal from LMFRs in normal operation and in the framework of decommissioning, IWGFR-98, Aix-enProvence, France (Vienna: IAEA)

Sridhar S 1996 J. Membrane Sci. 11373

Stade K Ch 1978 Operating experience in cleaning sodiumwetted components at the KNK nuclear power plant, IAEA/ IWGFR-specialists meeting on sodium removal and decontamination, IWGFR-23, Richland, Washington, USA (Vienna: IAEA) p. 17

Steele O P and Brehm W F 1978 Summary of sodium removal and decontamination programmes in the USA, IAEA/ IWGFRspecialists meeting on sodium removal and decontamination, IWGFR-23, Richland, Washington, USA (Vienna: IAEA) p. 151

Vacek J 1984 Alkali metal alcoholates, Patent No. CS 213119

Waimei Y, Dejun D, Huanfang G, Shunzhang H, Shuxia Z, Fenyang S, Zhongmin Y and Yungxing X 1997 Some techniques for sodium removal in CIAE, IAEA/IWGFR - technical committee meeting on sodium removal and disposal from LMFRs in normal operation and in the framework of decommissioning, IWGFR-98, Aix-en-Provence, France (Vienna: IAEA)

Waltar A E and Reynolds A B 1981 Fast breeder reactors (New York: Pergamon Press)

Welch F H and Steele O P 1978 Non-aqueous removal of sodium from reactor components, IAEA/IWGFR-specialists meeting on sodium removal and decontamination, IWGFR23, Richland, Washington, USA (Vienna: IAEA) p. 173

Wiess Von E Z 1964 Anorg. Allg. Chem. 332197 